\title{
66. Psikoterapi çevirmenliği: Psikososyal destek hizmetlerinde çevirmenin rolü ve önemi
}

Filiz ŞAN 1

\begin{abstract}
APA: Şan, F. (2021). Psikoterapi çevirmenliği: Psikososyal destek hizmetlerinde çevirmenin rolü ve önemi. RumeliDE Dil ve Edebiyat Araşturmaları Dergisi, (23), 1027-1041. DOI: 10.29000/rumelide.949989.
\end{abstract}

\section{$\ddot{O} \mathbf{z}$}

Son yıllarda alınan dış göçle birlikte, Türkiye'de ülke dilini bilmeyen kişilerin toplum hizmetlerine ulaşabilmesini olanaklı kılacak, çeviriye ve çevirmene duyulan ihtiyaç artmıştır. Söz konusu ihtiyacı karşlamak üzere sürdürülen toplum çevirmenliğinin uygulama alanlarından bir tanesi psikoterapi görüşmelerinin gerçekleştirildiği ruh sağlığı alanıdır. Konu ruh sağlığı olduğunda, danışanların profili ve ihtiyaçları, görüşme yöntem ve teknikleri, soru türleri gibi ilgili alanın uzmanlık bilgisiyle sürdürülen bir terapi süreci söz konusu olmaktadır. Türkiye'de bu tür terapilerde çeviriye ihtiyaç duyanların göçmenler olduğu dikkate alındığında, mevcut dinamiklere göç öncesi, göç sırası ve göç sonrası yaşadıklarının bir sonucu olan travmaların derinliği, kültür ve gelenek farklılıkları, terapiye olan bakış açısı gibi çok daha farklı faktörlerin de belirleyici şekilde eklemlendiği söylenebilir. Buna göre çevirmenin psikoterapideki görevinin, sadece kelimelerin başka bir dile aktarılmasıyla sınırlı olması mümkün görünmemektedir. Bu çıkarım, söz konusu süreçte çevirmenin, kültürler arası iletişim uzmanı olarak, terapideki rolünün araştırılmasını önemli hale getirmiştir. Buradan hareketle bu araştırmada psikoterapilerde görev alan çevirmenlerin rolü ve önemi ortaya koyularak, taraflar açısından işbirliğinin somutlaştırılması amaçlanmıştır. Bu amaçla bu çalışmada ruh sağlığı ve toplum çevirmenliği alanlarının kuramsal ve kavramsal çerçevesi oluşturulmuş, durumsallık ilişkisi bağlamında psikoterapideki dinamikler belirlenmiş ve çeviri sürecine etkisi açısından sorunsallaştırılmıştır. Yapılan araştırma ve değerlendirmeler sonucunda çevirmenlerin psikoterapilerdeki rolü ve önemi, uzman ve çevirmen işbirliği odağında ortaya konulmuştur.

Anahtar kelimeler: Toplum çevirmenliği, psikoterapi çevirmenliği, psikososyal destek çevirmenliği, ruh sağlı̆̆ı alanı çevirisi, çevirmen rolü

\section{Psychotherapy interpreting: the role and importance of interpreters in psychosocial support services}

\begin{abstract}
In recent years the need for translation services and translators for community services has increased with the rise in flow of migrant population to Turkey. One of the main fields of community interpreting, carried out to meet the community services need, is of mental health where psychotherapy interviews are conducted. Within this mental health field, there is a therapy process that is carried out with the relevant field of expertise, such as the profile and needs of the clients, interview methods and techniques, and question types. When we consider the main group of clients as migrants in Turkey, it is also essential to take into account pre-migration, migration and post-migration processes, traumas that appear as a consequence of these experiences, cultural
\end{abstract}

Dr. Öğr. Üyesi, Sakarya Üniversitesi, Fen-Edebiyat Fakültesi, Mütercim ve Tercümanlık Bölümü, Almanca Mütercim ve Tercümanlık ABD (Sakarya, Türkiye), fsan@sakarya.edu.tr, ORCID ID: oooo-0oo3-2158-3818 [Araştırma makalesi, Makale kayıt tarihi: 16.04.2021-kabul tarihi: 20.06.2021; DOI: 10.2900o/rumelide.949989]

Adres | Address

RumeliDE Dil ve Edebiyat Araştırmaları Dergisi $\quad$ RumeliDE Journal of Language and Literature Studies Osmanağa Mahallesi, Mürver Çiçeği Sokak, No:14/8 Osmanağa Mahallesi, Mürver Çiçeği Sokak, No:14/8

Kadıköy - İSTANBUL / TÜRKIYE 34714 Kadıköy - ISTANBUL / TURKEY 34714 e-posta: editor@rumelide.com

e-mail: editor@rumelide.com

tel: +90 505 7958124, +90 2167730616 phone: +90 505 7958124, +90 2167730616 


\begin{abstract}
differences and different therapautical approaches. Based on these facts, it is essential to question the interpreter's role via not only in means of transferring words to another language, but also as an intercultural communication specialist in theraphy. It is aimed to bring out the cooperation between related parties by revealing the role and importance of interpreters working in psychotherapies. For this purpose, in this study, the theoretical and conceptual framework of the fields of mental health and community interpreting has established, the dynamics of psychotherapy in the context of the contingency relationship were determined and problematized in terms of its effect on the translation process. As a result, the role and importance of translators in psychotherapies tried to be revealed in relation with expert and interpreter collaboration.
\end{abstract}

Keywords: Community interpreting, psychotherapy interpreting, translation and interpreting in psychosocial support, translation and interpreting in mental health, interpreter's role

\title{
Giriş
}

Bir ülkeye gelmek, hayat kurmak ve sürdürebilmek için gerekli olan tüm adımlarda, gittikleri ülkenin dilini bilmeyen kişiler çeviriye ihtiyaç duymaktadır. Her ne sebeple olursa olsun, ülkede bulunan yabancıların ihtiyaç duydukları hizmetleri alabilmeleri, temel bir insan hakkı olarak görülmelidir. Dolayısıyla ne zaman, neden, nereden, ne kadar süreliğine geldikleri ve uyum süreçlerinin nasıl ilerlediği soruları, söz konusu temel haktan yararlanabilmeleri için belirleyici olmamalıdır. Toplum çevirmenliği her ne kadar ülkemizde zaman zaman ihtiyaç duyulan bir alan olsa da, özellikle son yıllarda, Türkiye'nin aldığı büyük dış göçle birlikte geçici koruma altındaki kişilerin ihtiyaçlarının artmasıyla ön plana çıkan çeviri alanlarından biri haline gelmiştir.

Toplum çevirmenliği temel anlamda, "toplum hizmeti alanında; polis merkezlerinde, göçmen bürolarında, sosyal hizmet merkezlerinde, sağllk ve psikiyatrik tedavi merkezlerinde, okullarda ve benzeri kurumlarda; yetkililerle halk arasındaki iletişimi kolaylaştırmak amacıyla verilen sözlü çeviri hizmeti..." (Wadensjö, 1998, s. 33, akt. Kurultay ve Bulut, 2012, s. 79) olarak tanımlanabilir. Bu konuda ortaya atılan tanımların ve kapsamlarının ülkelerin durum ve ihtiyaçlarına göre farklılık gösterdiğini söylemek yanlış olmayacaktır. Yani bu bağlamda ortaya çıkan tanımlarda ülkedeki mevcut uygulamalardan hareket edildiği söylenebilir. Başka bir ifadeyle, çeviriye kimin, neden ve nerede ihtiyaç duyduğu, çeviri ihtiyacının kimler tarafından, nasıl karşılandığı, hangi alanlarda ne tür gereksinimlerin mevcut olduğu gibi soruların yanıtı genel çerçeveyi ortaya koyarken, aynı zamanda ülkenin toplum çevirmenliği bağlamında odağını da belirlemektedir. Öte yandan alanı tanımlamak, hangi uygulamaların bu tanımın içine girdiği, hangilerinin dışında kaldığı gibi bir ayrıma da götürmektedir. $\mathrm{Bu}$ tür bir ayrım toplum çevirmenliği gibi geniş bir alan için çeşitli soruları da beraberinde getirmektedir.

Türkiye'de toplum çevirmenliği tanımları olsa da hâlâ net ifade edilmeyen bazı hususların varlığından söz etmek mümkündür. Hukuk metinlerinin çevirisiyle mahkemede gerçekleştirilen çeviri etkinliği, tıp metinlerinin çevirisiyle hastanede (örneğin hasta-doktor arasında) gerçekleştirilen çeviri etkinliği metin türü, çeviri türü, mekan, zaman, sürece etki eden etmenler vb. bakımından zaman zaman birbirinden ayrı tutulmaktadır. Bu bağlamda şu sorular da akla gelmektedir: Ülkemizde gittikçe artan sağlık turizmindeki çeviri etkinliği toplum çevirmenliği olarak tanımlanabilir mi? Toplum Çevirmenliği

\begin{tabular}{r|l} 
Adres & Address \\
RumeliDE Dil ve Edebiyat Araşttrmaları Dergisi & RumeliDE Journal of Language and Literature Studies \\
Osmanağa Mahallesi, Mürver Çiçeği Sokak, No:14/8 & Osmanağa Mahallesi, Mürver Çiçeği Sokak, No:14/8 \\
Kadıköy - İSTANBUL / TÜRKIYY 34714 & Kadıköy - ISTANBUL / TURKEY 34714 \\
e-posta: editor@rumelide.com & e-mail: editor@rumelide.com, \\
phone: +90 505 7958124, +90 2167730616
\end{tabular}


yeterliliklerinde ${ }^{2}$ de yer alan spor çevirmenliği hangi açıdan toplum çevirmenliğinin alt alanı olarak görülmektedir? 1999 yllında yaşanan depremden sonra, daha önce hiç sözü edilmeyen, afet ve acil durum çevirmenliğinin de toplum çevirmenliğinin bir alt alanı olarak ifade edilmesi, dinamik bir yapıya tanım koyarak çerçeve çizmenin çok da mümkün olmaması olarak değerlendirilebilir mi? Çünkü örneklerden görüldüğü üzere ihtiyaç farklılaştıkça tanım da genişlemektedir. 3 Bir çeviri etkinliğini toplum çevirmenliğinin alanı içinde konumlandırmak için belirleyici olan nedir? Kim (mülteci, hasta, göçmen, afetzede, yabancı öğrenci, turist vd.) için çeviri yapıldığı, bu konumlandırmayı etkileyen bir husus mudur? Peki, sadece sözlü çeviri mi söz konusudur, yoksa yazılı çevirmenlik faaliyetleri de toplum çevirmenliğinin alt alanı olarak görülebilir mi? Bu sorular çeşitli açılardan yanıtlanabilmekte. Ancak yukarıdaki sorulardan da anlaşılacağı üzere toplum çevirmenliği alanında dinamik bir yapı hâkimdir ve buna göre durumsallığın her yönüyle etkili olduğu bu çevirmenlik alanını tanımlarken kesin bir sınır çizmek, bu alanın doğasına aykırı olarak yorumlanabilir. Türkiye'de özellikle son 5 yılda toplum çevirmenliği alanında yapılan araştırmaların sayı ve konu yelpazesi bakımından artışı dikkate alındığında4, bu konuların çeşitli açılardan irdelendiği görülmektedir. Aynı artışın önümüzdeki süreçte de devam etmesi muhtemeldir.

Çevirmenliğin her daim farklı dinamiklerinin olduğu bilinmektedir. Dünyada ve toplumda yaşanan her türlü gelişme çeviri alanına da farklı açılardan yansımaktadır. Konu ve alan ne olursa olsun, çeviriye ihtiyaç duyulan ortam ve koşulların, çeviri etkinliğine ve çevirmen kararlarına -özellikle Toplum Çevirmenliği söz konusu ise- etki ettiği söylenebilir. Bu açıdan düşünüldüğünde, çevirinin durumsal oluşu gözden kaçırılmayacak bir husustur. Buradan hareketle bilimsel çalışmalarda alana ve bazen konuya ya da duruma özgü, yani spesifik araştırmalara ihtiyaç duyulmaktadır. Bu anlamda, farklı ortamlarda çeviriye etki eden dinamiklerin incelenmesi ve bilimsel bir zeminde değerlendirilmesi alana katkı sağlayacaktır. Bu çalışmanın amacı, tam da bu yaklaşımı benimseyerek konusu, hedef kitlesi ve durumsallığı açısından toplum çevirmenliğinin bir alt alanı olan psikoterapi çevirmenliğini incelemektir. Türkiye'deki mültecilerin, yaşadıkları neticesinde ortaya çıkan ruh sağlı̆̆ı sorunlarını ele alan bilimsel çalışmalar olsa da, çeviriye ve çevirmene odaklanarak konuyu irdeleyen çalışmalar bulunmamaktadır. Çeviribilim alanında da toplum çevirmenliği ve onun alt alanı olan sağlık çevirmenliği son yıllarda araştırmalara konu olsa da, ruh sağlığı alanındaki çeviri faaliyetleri üzerine yapılmış herhangi bir araştırmaya rastlanmamıştır5. Bu bağlamda bilimsel bir literatürden söz etmek mümkün değildir. Oysa ülkemizde yaklaşık on yıldır ciddi travmalar geçirmiş insanlar yaşamakta ve birçok konuda olduğu gibi ruh sağlığı alanında da mültecilere yönelik çeşitli hizmetler sunulmaktadır. $\mathrm{Bu}$ açıdan değerlendirildiğinde bu konuyla ilgili araştırma gereksinimi ortaya çıkmaktadır.

\section{Amaç ve yöntem}

Ruh sağlığı çevirmenliği, sağlık çevirmenliği başlı̆̆ının altında ele alınabilse de, kendine özgü dinamikleri ve farklı özellikleri olması bakımından ${ }^{6}$ bu çalışmada psikoterapiye odaklanılarak sağlık çevirmenliğinden bağımsız işlenecektir. Burada amaç, söz konusu alanın diğer toplum çevirmenliği

Bkz. Mesleki Yeterlilik Kurumu, Toplum Çevirmenliği Ulusal Yeterlilik Kriterleri. Erişim Adresi: http://cdn.istanbul.edu.tr/FileHandler2.ashx?f=cevirmen-yeterlilikleri---toplum-cevirmeni---yayinlanan-taslak15.12.2018.pdf

Kurultay T. ve Bulut A. Toplum Çevirmenliği bağlamında Afette Rehber Çevirmenlik konusunu irdeleyerek, Toplum Çevirmenliğini bir uygulama alanı olarak konumlandırmışlardır. Bundan hareketle de Toplum hizmetlerinde çeviri hizmeti sunulan kişilere afetzedeleri de ekleyerek tanımı genişletmişlerdir (2012, s. 79).

Toplum Çevirmenliği alanında Türkiye'de yayınlanan araştırmalara dair detaylı bilgi için bkz. Şan ve Koçlu, 2020.

Bkz. Şan ve Koçlu, 2020.

Sağllk alanındaki çeviri hizmetleri konusunda araştırmalar gerçekleştiren Bernd Meyer de 2003 yılında yürüttüğü bir projenin çıktılarını paylaştı̆̆ çalışmasında, psikoterapi alanındaki çevirmenliğinde farklı belirleyicilerinin olduğunu ve söz konusu alanın özelinde incelemeler yapılması gerektiğini ifade etmektedir. (Bkz. Meyer, 2003, s. 179).

Adres $\mid$ Address

RumeliDE Dil ve Edebiyat Araşttrmaları Dergisi $\quad$ RumeliDE Journal of Language and Literature Studies Osmanağa Mahallesi, Mürver Çiçeği Sokak, No:14/8 Osmanağa Mahallesi, Mürver Çiçeği Sokak, No:14/8

Kadıköy - İSTANBUL / TÜRKIYE 34714 Kadıköy - ISTANBUL / TURKEY 34714 e-posta: editor@rumelide.com

e-mail: editor@rumelide.com

tel: +90 $5057958124,+90216773$ o 616 phone: +90 505 7958124, +90 216773 o 616 
alanlarından ayrılan özellikleri üzerinden çevirinin ve çevirmenin önemini ortaya koymak ve çevirmenle işbirliğinin gerekliliğine işaret etmektir. Bu amaçla yapılacak araştırmada kuramsal ve kavramsal çerçeve oluşturulacak, durumsallık ilişkisi bağlamında psikoterapi ve çeviriye etki edecek dinamikler belirlenecek ve irdelenecektir. Söz konusu alanda çeviriye ihtiyaç duyan kitlenin ağırlıklı olarak mültecilerden oluşması nedeniyle, değerlendirmeler bu kitle ve ihtiyaçları dikkate alınarak yapılacaktır. Buna göre çevirmenlerin psikoterapideki rolü ve durumu psikoterapi ve çevirmen açılarından irdelenerek ortaya koyulacaktır. Bu çalışmayla, ruh sağllğı alanındaki çeviri ve çevirmenlik faaliyetinin hassasiyetleri ve ayırıcı özellikleri konusuna dikkat çekmek ve farkındalık yaratmak hedeflenmektedir.

\section{Psikoterapi çevirmenliğinde uzman ile çevirmenin işbirliği}

Psikoloji ile çeviri arasında temasın olduğuna işaret eden ilk çeviribilimci, James Holmes olmuştur. Holmes 1972 yılında çeviribilimi tanımladığı ve bir bilim dalı olarak konumlandırmayı hedeflediği "The Name and Nature of Translation Studies" adlı bildirisinde, çeviribilimin alt alanlarından biri olan betimleyici çeviribilimde yapılan araştırmaları ürün odaklı, işlev odaklı ve süreç odaklı olarak sınıflandırmaktadır. Süreç odaklı betimleyici çeviribilim araştırmalarında, çeviri sürecinde çevirmenin zihnindeki "küçük kara kutu"da neler olduğu konusunun ele alındığını ifade eden Holmes, söz konusu dönemde bu konuda yürütülen araştırmaların yetersiz kaldığını da ifade ederek, "gelecekte zihindeki çeviri işlemiyle daha çok ilgilenileceğini ve "çeviri psikolojisi" ya da "psikoçeviribilim" olarak adlandırılabilecek bir araştırma alanı oluşacağını" umduğunu açıklamaktadır (2008, s. 112). Günümüzde Holmes’in öngördüğü ve işaret ettiği yönde araştırmalar yürütüldüğü bilinmektedir. Franz Pöchhacker, çeviribilimin sözlü çeviri konusundaki gelişim sürecini açıkladığı çalışmasında, psikoloji alanının sözlü çeviri süreci ile çok ilgilendiğinin ve çeşitli araştırmalar yapıldığının altını çizmektedir (2010, s. 86). Sesli düşünme, odaklanma, yorumlama, zihinsel ve bilişsel süreç vb. kavramlar üzerinden araştırılan çeviri edimi ve çevirmenin karar verme süreci, psikoloji ve çeviribilim disiplinlerinin birbirlerine temas ettiğini göstermektedir.

Çeviribilimin inceleme nesnesi olan çevirinin, doğası gereği çeşitli disiplinlerin bakış açısından yararlanma ihtiyacı göz önünde bulundurulduğunda hem çeviri eyleminin gerçekleştirilmesi hem de çeviri sürecinin her yönüyle açıklanması için çok boyutlu ve kapsayıcı bir yaklaşım benimsenmesi gerektiği söylenebilir. Bu da çeviribilimin alt alanlarında farklı düzeylerde işbirliğini gerekli kılmaktadır. Çeviribilimin ilk yıllarında ortaya atılan bilimsel yaklaşımlarda işbirliği konusu, özellikle Justa Holz-Mänttäri'nin (1984) çeviri eylemi kuramında vurgulanmaktadır. Kuramını Çeviri sürecine etki eden faktör ve eyleyenleri de dikkate alarak geliştiren Holz-Mänttäri, iş bölümüne dayalı toplumun, ancak işbirliği içinde olan eyleyenlerin, birbiriyle iletişim halinde olmaları, gerektiğinde de geri bildirimde bulunmaları durumunda, varlığını sürdürebileceğini belirtmektedir. Bu çalışmaya konu olan ve sözlü çeviri etkinliği odağında ele alınan psikoterapi çevirmenliğinde işbirliği, çok daha somut düzeyde, çeviri süreci boyunca sürdürülmesi zorunlu olan bir gereklilik olarak görülmelidir. İşbirliği ve diğer tüm hususları sorunsallaştıran hem saha ve eylem odaklı hem de bilimsel düzeyde araştırmalara, hatta alanlar arası etkileşime ihtiyaç vardır.

Psikoterapi çevirmenliğinde yine aynı iki disiplinin, bu sefer her yönüyle somut şekilde kesiştiği bir uygulama alanı ve onun ürünü olan inceleme nesnesi söz konusudur. Bu alandaki çeviri etkinliğine etki eden tüm dinamiklerin her yönüyle açıklanmasında, sadece psikoloji ve çeviribilimin değil; tıp, mülteci araştırmaları, sosyoloji ve benzeri disiplinlerin ortak bir zeminden bakış açısı geliştirmesi gereklidir (Cagala, 2006, s. 254). Bu bağlamda psikoterapi çevirmenliği tam da bu iki disiplinin

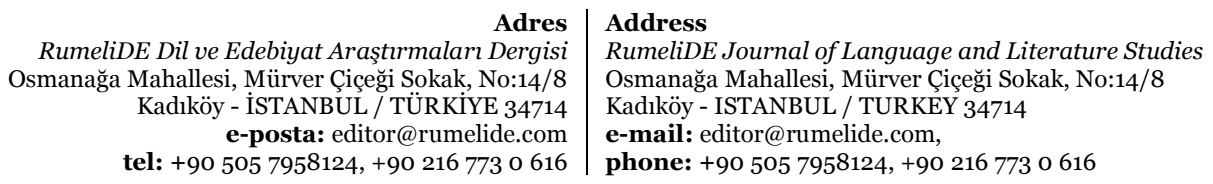


kesiştiği, etkileşimle beraber ilişki ve işbirliği kurarak yürütülmesi gereken bir etkinlik/eylem/süreç olarak görülmelidir. Şebnem Bahadır bu bağlamda bir iletişim durumundaki eyleyenleri etkileşim ortağı (Interaktionspartner) olarak ifade ederken, "etkileşim" kavramının, diyalogdan ibaret bir iletişimden ziyade, söz konusu iletişim süreci için önemli olan çevirinin “öncesi”, "sonrası”, ve "etrafındaki” tüm iletişim durumlarını kapsayacak şekilde tanımlanması gerektiğinin de altını çizmektedir (2010, s. 38).

Toplum Çevirmenliği söz konusu olduğunda işbirliğine bağlı bir etkileşimin gerekliliğini vurgulamak gerekir. Her ne kadar bu görüşmeleri iki dilli terapistlerin gerçekleştirmesi ideal olsa da böylesi terapistlere rastlamanın güç olacağı ortadadır. Dolayısıyla psikoterapi seanslarını çevirmen yardımıyla sürdürmek zorunluluktur (krş. Nuč, 2006, s. 263). Bu bağlamda süreç, dillerarası bir aktarımdan daha fazlasını, psikoterapi konusundaki yaklaşımları, terapi ve çalışma süreci bilgisini gerektirmektedir (Salman, 2007, s. 252). Çevirmen, ruh sağlığı uzmanı olmasa da ruh sağlığı uzmanlarının işinin gereklerini bilen ve çeviri kararlarında bu unsurları dikkate alan bir iletişim uzmanı olarak görülmelidir. Ruh sağlığı uzmanı da çevirinin kelimelerin aktarımından ibaret olmadığını ve çeviriye etki eden sözlü ve sözlü olmayan birçok faktörün belirleyiciliğiyle iletişimsel bir eylem olduğunu bilmelidir. Uzmanın işi ruh sağlığı desteği sunmak, çevirmenin işi ise bu desteğin verilmesini iletişimsel boyutta olanaklı kılmaktır.

\section{Mültecilerin psikoterapi ihtiyacı ve dinamikler}

Türkiye, özellikle 2011 yll itibariyle Suriye'de yaşanan çeşitli sorunlardan ötürü büyük bir dış göç almıştır. Göçün zorunlu olması ve geliş şekillerinin farklılık göstermesi nedeniyle sığınmacı, mülteci, ilticacı gibi kavramlar birbirinin yerine geçecek ve anlam kargaşası yaratacak şekilde kullanılırken, resmî ifade "geçici koruma altındaki yabancılar" şeklinde formüle edilmiştir. Ancak bu kavramların irdelenmesi ve tanımlanması bu çalışmanın sınırlarını aşacağından bu çalışmada mülteci kavramı kullanılmıştır.

Suriye'de yaşanan savaş koşulları nedeniyle ülkelerini terk etmek zorunda kalan mültecilerin yaşadıkları olumsuz şartların beraberinde getirdiği psikolojik ve travmatolojik sorunlara, yeni yaşam şartlarına uyum sürecindeki zorluklar da eklenmektedir. Ülkemizde uyum sürecini kolaylaştırmak ve hızlandırmak amacıyla birçok çalışma yapılsa da mültecilerin geldikleri ülkenin dilini bilmemeleri bu süreci bir ölçüde olumsuz yönde etkilemektedir (Şan ve Koçlu, 2018, s. 8). Uyum kavramı her ne kadar, "toplumsal çevreye veya bir duruma uyma, uyum sağlama, intibak, entegrasyon" (TDK) olarak tanımlansa da bu kavrama bulundukları yere uyum sağlamanın ötesine geçen, daha geniş bir anlam yüklemek gerekir. Çünkü uyum, iki tarafın hazır bulunmasıyla kurulan iletişim sayesinde gerçekleşecek etkileşimin sonucudur. Bu açıdan bakıldığında, birbirini anlamak bu sürecin ilk basamağını oluşturmaktadır. Bu bağlamda, çeviriye ihtiyaç duyan mültecilerin ruh sağlığı açısından durumunu anlamak gerekir.

Mültecilerin psikolojik sorunları konusunu araştıran Hatice Demirbaş ve Ece Bekaroğlu, ruh sağlığını olumsuz etkileyen stres etmenlerini, göç öncesi, göç sırası ve göç sonrası olmak üzere üç ana başlık altında ele almaktadır. Travmatik yaşantılar, aile kayıpları ve şiddete maruz kalma veya tanık olma gibi yaşanmışlıklar göç öncesi etmenler arasında yer alırken, travmatik yaşantılar, fiziksel/psikolojik şiddet/taciz ve zorlu yaşam koşulları gibi ağır olaylar da göç sırasında eklenen etmenler olarak sıralanmaktadır. Göç sonrası stres etmenleri zaten büyük ruhsal yüklerle gelmiş olan mültecilerin durumunu daha da zorlayıcı bir hale getirmektedir. İltica talebi, gelecekle ilgili belirsizlik, barınma,

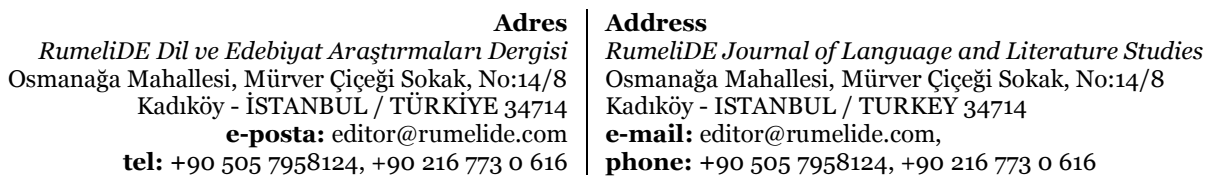


beslenme, arkadaş edinme vb. sosyal yaşam korkusu, maddi güçlükler, işsizlik, sosyal yalnızlık, geçmişe özlem, zorlu kamp yaşantıları, kültürel engeller, dil sorunu ve yeni rol ve sorumluluklar gibi, sayıca oldukça fazla etmen söz konusudur. Mültecilerde yaşadıkları zorlu şartların etkisiyle bunaltı, depresyon, psikosomatik belirtiler, uyku düzensizliği, dikkat eksikliği, intihar, agorofobi ve travma sonrası stres bozukluğu gibi ruhsal bozukluklar ortaya çımaktadır (Demirbă̆ ve Bekaroğlu, 2013, s. 13-14).

Türkiye'de mültecilere yönelik gerçekleştirilen psikoterapilerde bu üç döneme dair birikmiş sorunların etkisi olduğu düşünüldüğünde, ruh sağlığı desteği konusundaki ihtiyacın büyüklüğü de ortaya çıkmaktadır. Çünkü üç ayrı dönem gibi aktarılan bu travmatik olaylar, birbirini aralıksız takip eden, geniş bir zaman dilimine yayılmış ağır yaşanmışlıklardır. Bu nedenle de ruh sağlı̆̆ı desteğini ihtiyaç değil zorunluluk olarak görmek gerekir. Ruh sağlığı desteğinin hedeflenen sonuca ulaşmasında farklı terapi uygulamaları, teknikler ve yöntemler kullanılmaktadır. Danışanın mülteci olması, bu destek sürecinin hedef kitlesi bakımından değerlendirilmesini gerekli kılmaktadır. Mültecilerin, ruh sağlığı desteğinde gerekli iletişimin kurulmasını sağlayacak araç olan dili mültecilerin bilmiyor olması durumunda, terapinin uygulanabilmesi, doğal bir sonuç olarak, imkânsızdır. Çeviri ihtiyacını ortaya çıaran bu durum, dili bilen herhangi birinin danışan ve uzman arasında çeviri yapmak üzere görüşmeye katılmasıyla basitçe çözülecek bir sorun değildir. Psikososyal destek görüşmelerinde danışan ve uzman arasında kültür farklılığının da olması, bu sorunu çok daha zorlu bir düzeye taşımaktadır. Çünkü dil ve kültür ilişkisi, iletişimin amaçlı olarak sürdürüldüğü bu tür görüşmelerde çok önemli rol oynamaktadır. Söz konusu farklılıklardan doğan bu dinamikler, psikososyal destek sürecinde etkili unsurlarla birlikte dikkate alınarak bütüncül bir değerlendirme yapılmasını gerekli kılmaktadır.

\section{Ruh sağlığı alanı ve psikoterapide görüşme teknikleri ve yöntemleri}

Mültecilerle gerçekleştirilen psikoterapi görüşmelerinin amacı ve görüşmeler sirasında uzman tarafından kullanılan teknik ve yöntemler, bu ortamdaki çeviri etkinliğinin bir dilden başka bir dile düz bir aktarımla sınırlı olmadığını açıklar niteliktedir. Elif Güneri-Yöyen, klinik görüşmenin kendine özgü teknikler içeren özgün bir iletişim becerisi olduğunu ifade etmektedir. Ona göre klinik görüşme iyi uygulandığında, uzmanın hedefine ulaşmasını ve sorumluluğunu yerine getirebilmesi için gerekli zeminin oluşmasını sağlayan temel bir araçtır. Bu tür profesyonel bir desteği sohbetten ayıran özelliklere değinen araştırmacı, aralarındaki farkı gerekçeleriyle açılamaktadır. Güneri-Yöyen klinik görüşmelerin özgün bir zihinsel kavrayış içerdiğini ifade ederken, içerisinde etik ve estetik öğeleri barındıran formülasyonu ile ilişki kurma, yansıtma, soru sorma, açık etme, görünür kılma, özetleme, yüzleştirme, yorumlama gibi içeriği ile hasta ile olumlu bir ilişki kurulmasını ve sorunları çözme becerisinin geliştirilmesinde hastaya yardım eden bir iletişim tekniği olarak sohbetten farklı olduğunu açılklamaktadır. Buna göre klinik görüşme, sohbetin çok ötesinde kesin bir amaca hizmet edecek bir içeriğe odaklanmaktadır. Sohbet ise rastlantısal ve gelişigüzel konulara odaklanır. Bu bağlamda klinik görüşme süreci, tematik tutarlılığı ve sürekliliği ile yönelimi kısıtlllık üzerine kurulu bir görüşmedir. Sohbetin yönelimi ise ilişkiseldir. Burada bir ana konu yoktur veya var olan konuya ek yeni konular ile duygulanımsal ve düşünsel süreçler dağınıktır, tematik değildir. Güneri-Yöyen’e göre klinik görüşmede psikoloğun ve hastasının rollerinin olması da önemli bir farklılıktır. Buna göre bu roller zaman sürecinde sergilenmek üzere uygulanmaktadır. Buna karşın sohbette tarafların rolleri ve zaman kısıtlılığı bulunmaz. Başka bir ayrım da normlardır. Klinik görüşmede kişiler arası ilişkilere dair normlar bulunmakta ve görüşmeyi yapan psikolog bu normlar çerçevesinde sorumluluk almaktadır. Sohbette ise kişiler arası ilişkileri düzenleyen normlar bulunmamakta ve bununla birlikte tarafların

\footnotetext{
\begin{tabular}{r|l} 
Adres & Address \\
RumeliDE Dil ve Edebiyat Araşttrmalar Dergisi & RumeliDE Journal of Language and Literature Studies
\end{tabular} Osmanağa Mahallesi, Mürver Çiçeği Sokak, No:14/8 Osmanağa Mahallesi, Mürver Çiçeği Sokak, No:14/8 Kadıköy - İSTANBUL / TÜRKIYE 34714 Kadıköy - ISTANBUL / TURKEY 34714 e-posta: editor@rumelide.com e-mail: editor@rumelide.com, tel: +90 505 7958124, +90 2167730616 phone: +90 505 7958124, +90 2167730616
} 
birbirlerine karşılıklı sorumlulukları söz konusu olmaktadır. Bu çerçevede ifade edilen son fark, klinik görüşmenin seçilmiş, planlanmış, organize edilmiş bir iletişim programı bulunurken, sohbette herhangi bir hazırlık bulunmamasıdır (Güneri-Yöyen, 2020, s. 9).

Sohbetle bu kadar bariz farklar barındıran bir iletişim ortamının, çeviri açısından da "basit" bir diyalog olarak görülmemesi gerektiği ortadadır. Görüşmenin gelişigüzel olmayışı, amaçlı bir iletişim ortamının oluşturulması, çevirmenin bu görüşmenin etkililiği açısından oynadığı rolün önemini de net olarak görünür hale getirmektedir. Çevirmen, amaçlı olarak yürütülen bu akışın parçasıdır. Terapinin bir parçası olarak çevirmen, söyleneni aktarıyor olmanın ötesine geçerek ve farkındalığı üst düzeye taşıyarak amaca hizmet edecek kararlar almalıdır.

Psikoterapide uzmanın tercih edeceği yöntemlerin uygulanmasıyla birlikte belirli aşamalar söz konusudur. Güneri-Yöyen bu sürecin giriş, veri toplama, değerlendirme, tedavi planı oluşturma, izlem, takip çalışması yürütme ve sonlandırma aşamalarından oluştuğunu ifade etmektedir. Psikoterapi sürecinde uzman etkili iletişim becerilerini profesyonel olarak uygulamaktadır. Araştırmacıya göre, bu süreçte etkin dinleme, empati kurma, geri bildirim verme, iletişimde uyumlanma, saygı, koşulsuz kabul, gizlilik ve saydamlık gibi faktörler etkili iletişimde uzman ve danışan arasındaki görüşmenin ayrılmaz bir parçasıdır (2020, s. 10).

Terapi sırasında kullanılan tekniklerin ve yöntemlerin çeşitlilik gösterdiğinden yukarıda bahsedilmişti. Bu tekniklerin ve yöntemlerin bazıları yansıtma, yapılama, özetleme, yeniden çerçeveleme, açıklık getirme, yorumlama ve yüzleşmedir. Terapi sürecinde tercih edilen teknikler iki düzeyde ele alınmaktadır: Temel düzey ve ileri düzey teknikler. Temel düzey teknikleri arasında teşvik etme, duygu yansıtması, içerik yansıtması, açı uçlu ve kapalı uçlu soru sorma, yüzleştirme, kendini açma, özetleme, danışanı gözlemleme, cesaretlendirme, yeniden ifade etme, odaklanma, anlamı yansıtma, yorumlama, bilgi verme gibi teknikler vardır. İleri düzey tekniklerde ise bu alandaki kuramlara ait stratejiler ve müdahaleler söz konusu olmaktadır. Bu kapsamda Gestalt kuramı, davranışçı kuramı, akılcı duygusal davranış kuramı, bilişsel kuram gibi teknikler ve yöntemler vardır (Yüksel-Şahin, 2019, s. 41). Bu araştırma kapsamında ruh sağlığı alanındaki tüm teknik ve yöntemlere yer vermek bu çalışmanın odağını kaybettirecektir. Bu nedenle özellikle çeviri ve çevirmenlik açısından önemli olabilecek birkaç tekniğe değinmek yararlı olacaktır.

Bunlardan en önemlisi, ruh sağlığı desteğinin ilk aşamasını oluşturan ön görüşme sürecinde kullanılan yapılama tekniğidir. Söz konusu teknik, danışanın ilk oturumda ön görüşme sırasında bilgilendirilmesini ve sonraki görüşmelerde ihtiyaç olması durumunda bilgilendirmenin yeniden yapılmasını kapsamaktadır. Bu çerçevede özellikle bu görüşmelerin kurallarını ve genel süreç konusundaki bilgileri paylaşmak amaçlanmaktadır. Yapılama tekniği sadece bilgi verilmesiyle değil bilginin nasıl verileceğiyle de ilişkilidir. Uzman, gerekli koşulları sağlayarak hem sözel hem de ses tonu, jest ve mimikler gibi sözel olmayan davranışlarını etkili şekilde kullanmaktadır. Ruh sağlığı alanındaki çalışmalara göre süreç hakkında bilgi verilmesi uzmanın ve danışanın görev ve sorumlulukları hakkında uyulması beklenen kurallar konusunda bilgilendirmeler yapılması, görüşmelerin olumlu sonuçlanması için atılan ilk adımlardan biridir (Yüksel-Şahin, 2019, s. 47). Yapılama tekniği konusunda çevirmenin bilgilendirilmesi, söz konusu hassasiyetlerin onun açısından da dikkate alınmasına olanak sağlayacaktır. Çünkü bu görüşme, terapinin bir parçası olup sadece bilgi aktarmayı içeren bir konuşma değildir. Ön ve ilk görüşmede olduğu gibi terapi sırasında da çeşitli aşamalarda çok farklı teknik ve yöntemler uygulanmaktadır. Burada hangi tekniği veya yöntemi kullanacağına karar veren uzmandır.

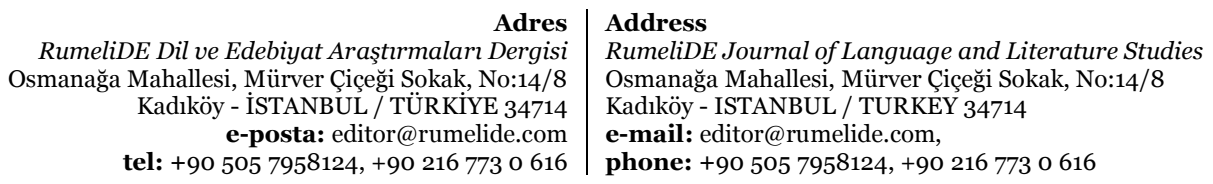


Danışanın görüşmenin gidişatındaki durumu uzman kararları açısından belirleyicidir. Uzmanın görüşmeler sırasında tercih ettiği soru şekilleri dahi belirli amaçlar doğrultusunda belirlenmektedir. Fulya Yüksel-Şahin, soru sorma tekniğini genel anlamda kapalı uçlu sorular ve açık uçlu sorular olmak üzere iki başlık altında açılamaktadır. Kapalı uçlu sorular uzmanın belirli bir bilgiye ihtiyacı olduğu durumlarda özellikle tercih edilir. Bu tür sorulara verilen cevaplar "evet, hayır" ya da belirgin bir bilgiyi içerecek şekilde cevaplanır. Örneğin, "İlaç kullanıyor musunuz?”, "Babanızla konuşurken öfkenizi kontrol edebildiniz mi?” vb. açık uçlu sorularda danışanın konuşmaya açıkça davet edilmesi söz konusudur. Burada amaçlanan, danışanın kendisini açarak, düşünceleri, duyguları, davranışları ve istekleri hakkında ayrıntılı bilgiler vermesidir ve bu açıdan sorular önemlidir. Sorular ne, nerede, ne zaman, kim, nasıl gibi zamirler yardımıyla sorulur. Danışmanın görüşmeye danışanın beklentisinin ne olduğunu sorarak başlaması ya da ileriki görüşmelerde daha önceki görüşmelerde sözü edilen sorunlar konusunda ne söylemek istediğini sorması bu soru tiplerine örnek olarak gösterilebilir. Bu tür soruların bir başka faydası ise danışanın belirli bir noktaya odaklanmasını sağlıyor olmalarıdır. Uzman, danışanın anlattığı bir sorunla ilgili olarak "Detaylı açılar mısınız?", "Şu anda neler hissediyorsunuz?”, "Şu anda neler düşünüyorsunuz?”, "Daha iyi anlamam için örnek verebilir misiniz?" gibi sorular yönelterek, danışanın söylediklerini daha iyi anlayacak, hem de danışanın duygularına ve düşüncelerine odaklanmasına imkân sağlamış olacaktır. Bu soru tekniklerinde dikkat edilmesi gereken hususlardan bir tanesi sürecin sadece soru-cevap şeklinde yürütülmemesi ve özellikle niçin ve neden sorularıyla sürdürülmesidir. Özellikle ilk görüşmelerde bu tür bir yaklaşım biçimi danışana sorguya çekildiğini hissettirecek ve savunmacı cevaplar vermesine neden olacaktır (2019, s. 54-56). Yüksel-Şahin'e göre terapi süresince danışanın sözlü olarak ifade ettikleri ile birlikte sözel olmayan davranışları da önemlidir. Bu nedenle danışman yani uzman, danışanı iyi şekilde gözlemler ve terapi sırasında tercih edeceği tekniklere, danışanın sözel ve sözel olmayan davranışlarına bakarak karar verir. Bununla birlikte uzmanın kendi davranışları ve ifadeleri de terapinin amacına ulaşabilmesi açısından büyük bir öneme sahiptir. Uzmanın vücudunun danışana doğru yönelmiş olması, danışanın yüzüne doğru bakarak gözleriyle iletişim kurması, uygun durum ve biçimde baş sallaması, yüz ifadesi ve ses tonu, duruma uygun el hareketleri yapması, genel olarak herhangi bir huzursuzluk hissi yaratmayacak şekilde durması gerekmektedir (2019, s. 43).

Terapi süreci yukarıda da söz edildiği gibi birçok yöntem ve teknikle yürütülmektedir. Yukarıda örnek olarak açlklanan birkaç husus ve teknik üzerinden bile psikoterapinin ne kadar bilinçli ve amaçlı tercihlerle, uzman kararlarıyla yürütülen bir süreç olduğu, net bir biçimde görülmektedir. Bu sürecin bir parçası olan çevirmenin bu teknik ve yöntemlere, arka planda yatan derin uzmanlık bilgisine bir psikolog, psikiyatr veya psikolojik danışman kadar sahip olması elbette beklenemez, ancak söz konusu terapi sürecini aksatmayacak düzeyde bilgilendirilmesi, uzmanın neyi neden yaptığını bilmesi, soru şekillerindeki amacın ne olduğu ya da danışanın verebileceği ani, fevri, kontrolsüz, saldırgan tepkiler karşısında nasıl davranması gerektiği gibi konularda farkındalık kazanmasının gerekliliği açıcça ifade edilmelidir. Bu tür terapilerde çeviriye ihtiyaç duyanların, derin travmalar yaşamış mülteciler olduğu dikkate alındığında, mevcut dinamiklere travmaların derinliğii, kültür ve gelenek farklılıkları, terapiye olan bakış açısı gibi çok daha farklı faktörlerin de belirleyici şekilde eklemlendiği söylenebilir. Bu da çevirmeni sürece etki eden aktörlerinden birisi olarak önemli hale getirmektedir.

\section{Psikoterapide çevirmenin rolü ve sürece etki eden unsurlar}

Çevirmenin profesyonel olması istenilen bir durumdur, ancak sahadaki uygulama gerçekçi şekilde değerlendirildiğinde, profesyonellikten uzak bir işleyişin hâkim olduğunun söylenmesi gerekir. Bunun başlıca iki nedeni vardır. Birincisi çevirmen profilidir. Bu konuda sayısal bir oran olmasa da Türkiye'de

\section{Adres $\mid$ Address}

RumeliDE Dil ve Edebiyat Araşttrmaları Dergisi $\quad$ RumeliDE Journal of Language and Literature Studies Osmanağa Mahallesi, Mürver Çiçeği Sokak, No:14/8 Osmanağa Mahallesi, Mürver Çiçeği Sokak, No:14/8 Kadıköy - İSTANBUL / TÜRKIYE 34714 Kadıköy - ISTANBUL / TURKEY 34714 e-posta: editor@rumelide.com tel: +90 505 7958124, +90 2167730616 phone: +90 505 7958124, +90 2167730616 
bu alanda çeviri yapan kişilerin büyük bir kısmının çeviri eğitimi almamış olduğu bilinmektedir. Hatta toplum çevirmenliğini konu alan çeşitli araştırmalarda toplum hizmetlerinde ülke dilini bilmeyen kişilere çoğu zaman eş, akraba, komşu, arkadaşlar ve hatta çocukların eşlik ettiği vurgulanmaktadır (Bkz. Bahadır, 2015, s. 48; Ross, 2018, s. 285; Salman, 2007, s. 252; Şan ve Kahraman-Duru, 2020, s. 821; Turan, 2016, s. 221-126). Türkiye'de ani gelişen ihtiyaç profesyonel çevirmenlerle değil de dil bilen kişilerin görevlendirilmesiyle karşılanmıştır. Bu da çevirmenlerin doğrudan kendi deneyimleriyle gelişmeleri anlamına gelmektedir. Öte yandan çevirmenlerin sahada birlikte çalıştığı kişilerin de bu konuda bilinç eksikliği olması sorunların daha da artmasını beraberinde getirebilmektedir. Bu açıdan düşünüldüğünde, sürece etki eden unsurların da bu çerçevede ele alınması gerekir.

Tüm çeviri türlerinde ve alanlarında olduğu gibi burada da belirleyici hususlar vardır. Bu da özellikle toplum çevirmenliğinde gerçekleştirilen çevirilerin durumsal oluşunu akla getirmektedir. Üstelik çevirmenin burada da kısmen sözü edilen psikoterapi sürecini ve yöntemlerini, yani alan bilgisini bilmesi çok önemli olsa da ideal bir süreç hedefleniyorsa, yeterli olmamaktadır. Aynı zamanda psikoterapistin de çevirmenle nasıl çalışılacağı konusunda bilgi sahibi olması gerekir. Çünkü çevirmenin psikoterapideki görevi, sadece kelimelerin başka bir dile aktarmak değil, bir işbirliği yapmaktır. Bu durumu ortaya koyabilmek için ruh sağllğı alanında yürütülen süreç, (a.) terapi, (b.) terapi öncesi ve (c.) terapi sonrası olarak irdelenecektir. Öncelikle terapi sırasında belirleyici olan hususlarla başlanmasının nedeni, bu hususların uzman ve çevirmen arasındaki işbirliğini gerekçelendiriyor nitelikte olmasıdır. Burada elde edilen bilgilerle terapi öncesi ve sonrası çalışmalarının gerekliliği de açıklanmış olacaktır.

\section{a. Terapi}

Psikoterapi uygulamalarındaki dinamiklerle birlikte çeviriyi ilgilendiren ve terapi sürecine etki eden birçok unsur bulunmaktadır. Bu unsurlarda işbirliği değişmez koşul olarak yer bulmaktadır. Ancak bu işbirliği rollerin karışmasına neden olmamalıdır. Uzmanla çevirmenin bu ilişki içerisinde üstlendikleri roller belli olmalıdır. Rollerin karışması özellikle mülteci çevirmenliğinde sıkça rastlanan bir durumdur. Ashley Marc Slapp'e göre çevirmen sadece söyleneni aktaran değil, aynı zamanda farklı süreçlerde de (örnek olarak form doldurma, onam formu açıklama ya da sağllk kontrolünden geçerken tetkik işlemlerine eşlik etme, randevu alma vb.) çeşitli roller üstenen kişidir (2004, s. 26). Toplum çevirmenliğinin alt alanlarında genellikle mağduriyet yaşayan kişilerin kendi dilini ve kültürünü bilen çevirmene yakınlık hissetmesi ve bağ kurması, çevirinin diğer alanlarına göre daha sık söz konusu olmaktadır (Slapp, 2004, s. 17; Salman, 2007, s. 253). Bunun en önemli nedenlerinden biri olarak, toplum çevirmenliğinde genellikle hâkim olan güç asimetrisinin etkisiyle, ülkenin dilini bilmeyen kişinin bir tür çaresizlik yaşaması ve çevirmeni sorununa çözüm üretecek kişi olarak görmesi gösterilebilir. Oysa psikoterapi örneğinde çevirmen, terapiye yön veren ve süreci yöneten kişi değil, sürecin gerçekleşmesi için iletişim bariyerini ortadan kaldıran kişidir. Bu süreç, uzman ve çevirmenin birlikte çalışmasını gerektirse de çevirmenin rolünün danışan tarafından biliniyor ve benimseniyor olması gerekmektedir.

Çevirmen, rollerin karışmaması için görev ve sorumluluklarının sınırını bilmelidir. Terapide danışanın açılması için çevirmenin varlığından rahatsızlık duymaması önemlidir. Tam da burada söz konusu sınırı doğru ayarlamak gerekir. Çevirmen, görev sınırlarını aşmayacağı ve danışanın kendisini rahat hissedeceği mesafede durmalıdır. Sınır koyma, çevirmenin kendisini koruması için de bir siper görevi görebilmektedir. Çünkü sınırsızlık çevirmenin de duygusal olarak etkilenmesine neden olabileceği gibi, onu görev aşımına da götürecektir. Bu aşım, çevirmenin üstlendiği sorumluluğu da etkileyebilir. Bu

\footnotetext{
Adres $\mid$ Address

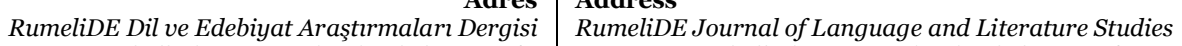
Osmanağa Mahallesi, Mürver Çiçeği Sokak, No:14/8 Osmanağa Mahallesi, Mürver Çiçeği Sokak, No:14/8 Kadıköy - İSTANBUL / TÜRKIYE 34714 Kadıköy - ISTANBUL / TURKEY 34714 e-posta: editor@rumelide.com e-mail: editor@rumelide.com, tel: +90 505 7958124, +90 2167730616 phone: +90 505 7958124, +90 2167730616
} 
bağlamda, çevirmenin psikoterapi sürecinde üstlendiği sorumluluğun farkında olması ve nerede durması gerektiğinin, ne zaman inisiyatif alabileceğinin bilincinde olması gerekmektedir. Sorumluluk üstlenme, inisiyatif alma ve karar verme sözlü çeviri etkinliğinde her zaman üzerine araştırmalar yapılan unsurlardır (Bahadır, 2007, s. 242). Psikoterapi çevirmenliğinde bu unsurlar daha da önemli hale gelmektedir. Önceki bölümde açıklanan görüşme teknikleri, terapide amaçlı ve daha önceden belirlenmiş bir sürecin takip edildiğini ortaya koymuştur. Bu açıdan düşünüldüğünde, ifadelerin amaçlı olması çevirmenin verdiği kararlarda da dikkate alınması gereken önemli bir husustur. Slapp’e göre, mültecilerin dilini bilmenin yanı sıra kültürünü de biliyor olması, çevirmenin hem sözel hem de sözel olmayan ifadelere açılılı getirmesini gerekli kılabilir. Uzmanın söylemek istediğini, danışanın kültür farklılığı veya arka plan bilgisi eksikliği nedeniyle anlamaması buna örnek olabilir (2004, s. 22). Danışanın yanıtından anlaşmazlığı fark eden çevirmenin, uzmanın yanlış bir yargıda bulunmaması için açımlama yaparak konuya açılık getirmesi gerekebilir. Eğer herhangi bir müdahalede bulunmazsa uzmanın, danışanı bağlantısız ve kopuk yanıtları nedeniyle yanlış değerlendirmesine neden olabilir. $\mathrm{Bu}$ tür müdahalelerde bulunulması konusunda çevirmen inisiyatif alarak terapi sırasında mı yoksa sonrasında mı bilgilendirmede bulunacağına karar verebilmelidir.

Psikoterapi çevirmenliğinde empati de göz ardı edilecek bir husus değildir. Çeviri, düz anlamda anlama ve aktarma süreci olarak görüldügünde, söyleneni bağlam içerisinde anlayabilmek ve terapi sürecine hizmet edecek farkındalıkla aktarmak için empatinin gerekli olduğunu söylemek yanlış olmayacaktır. Burada empatinin çeviri eyleminin gerçekleştirilebilmesi için kurulduğu unutulmamalıdır. Empati, çevirmenin danışanın duygu durumunu anlayabilmesi, söylediklerini, söylemek istediği şekilde anlaması ve aktarımı da iletişimsel sürecin aksamayacak şekilde gerçekleştirilmesi için önemli bir faktördür. Ancak empati konusunun beraberinde getirdiği tehlikeler de vardır; çevirmenin danışanla fazla empati kurması, kendisinin psikolojik açıdan olumsuz etkilenmesine neden olabilir. Toplum çevirmenliği söz konusu olduğunda, insani anlamda çok etkileyici hikâyelerle karşı karşıya kalınabilmektedir. Rana Kahraman, bu konuyu mülteci kamplarındaki durumu açıklayarak irdelemektedir. Sığınma başvurusunda bulunanlar için çeviri yaparken, bu insanlarının çoğunun tecavüz ve işkence gibi çeşitli yaşanmışlıkları olduğunu ifade ederek, bu çeviri ortamlarında karşılaşılan koşulların çevirmeni ister istemez hem fiziksel hem de psikolojik olarak zorladığının altını çizmektedir. Araştırmacı, bunların çevirmenin karar alma süreçlerini de etkileyebileceğini ifade etmektedir (2010, s. 42). Bununla birlikte çevirmenin danışanla benzer bir geçmişe sahip olması da muhtemel bir durumdur. Bu ihtimalin de göz ardı edilmemesi gerekir. Bu ihtimal söz konusu olsa da olmasa da çevirmenin empati kurma çabası, durum karşısında mesafeli kalmasını zorlaştırabilir (krş. Haenel, 2016, s. 837). Bu da onun tarafsız olmasını engelleyip psikolojik açıdan olumsuz etkilenmesine neden olabilir.

Tarafsızlık, insanın söz konusu olduğu tüm durumlarda sınıları ve olabilirliği bakımından tartışılmaktadır. Ancak aynı yoğunlukta, profesyonel iş yaşamındaki gerekliliği de ifade edilmektedir. Toplum çevirmenliğinin tüm alanlarında, insani olarak çevirmenin tarafsız kalmasının diğer çeviri türlerine kıyasla daha karmaşık olduğu bilinmektedir (Slapp, 2004, s. 26). Yürütülen faaliyet, uzman ve çevirmenin ortak bir amaca hizmet etmesi nedeniyle işbirliğini gerektirmektedir. Bu açıdan çevirmen taraf gibi görünse de söylenenin söylendiği gibi aktarılmasının psikolojik tanı koyulması ve tedavi sürecinin takibi açısından terapi ortamında tarafsız kalması son derece önemlidir.

Çeviride her daim önemli bir rol oynayan güven konusuna da bu noktada değinmek gerekir. Çeviri söz konusu olduğunda güven bir ön koşuldur. Karşılıklı olarak, konuştukları dilleri bilmeyen kişilerin, güvenmekten başka çarelerinin olmadığı çevirmene aynı zamanda şüpheyle baktıkları da

\footnotetext{
\begin{tabular}{r|l} 
Adres & Address \\
RumeliDE Dil ve Edebiyat Araşttrmaları Dergisi & RumeliDE Journal of Language and Literature Studies
\end{tabular} Osmanağa Mahallesi, Mürver Çiçeği Sokak, No:14/8 Osmanağa Mahallesi, Mürver Çiçeği Sokak, No:14/8 Kadıköy - İSTANBUL / TÜRKIYE 34714 Kadıköy - ISTANBUL / TURKEY 34714 e-posta: editor@rumelide.com e-mail: editor@rumelide.com, tel: +90 505 7958124, +90 2167730616 phone: +90 505 7958124, +90 2167730616
} 
bilinmektedir. Çoğu zaman kişiler "doğru” bir aktarım gerçekleştiğini ummaktan başka bir şey yapamazlar. Taraflardan biri çeşitli travmalar yaşamış mülteciler olunca güven, söylenenin aktarılıp aktarılmadığının daha da ötesine geçmektedir. Çünkü bu tür durumlarda kişiler anadilini konuşan ve anlaşabildiği çevirmene ya çok güvenirler ya da yaşadıkları nedeniyle zaten ürkek ve korkmuş oldukları için ciddi bir güvensizlik duyabilirler. Konu psikoterapi olduğunda ise durum daha da önemli hale gelmektedir. Bu tür terapilerde kişilerin iç dünyasını açması başlı başına güvene bağlı bir husustur. Başarılı bir terapi süreci hedefleniyorsa, danışan, uzmanda olduğu gibi çevirmene de güven hissetmelidir. Burada, yukarıda sözü edilen rollerin karışmamasına da dikkat edilmesi önemlidir, çünkü danışan çevirmene, dilini konuşması nedeniyle, uzmandan daha fazla yakınlık hissedip daha çok güvenebilir. $\mathrm{Bu}$ da terapinin istenilen sonuçları vermemesine neden olabilir. Danışanın, çevirmenin terapide bulunma nedeni ve görevinin sınırları konusunda farkındalığı olmalıdır. $\mathrm{Bu}$ düzeyde ve çerçevede bir güvenin sağlanması için, özellikle terapi öncesinde danışanın bilgilendirilmesi ve çevirmenle tanıştırılarak görev ve sorumlulukları konusunda bilinçlendirilmesi gereklidir. Bununla birlikte, çok önemli olan hususlardan bir tanesi de bir danışanın terapilerinde her zaman aynı çevirmenin görev almasıdır. Uygulama sahası dikkate alındığında bu her zaman mümkün olmasa da gerekli olduğu bilinmelidir. Sözü edilen güven duygusu bir çevirmenle kurulmuşsa, sürecin sağlıklı ilerlemesi için, bir sonraki terapide farklı bir çevirmen tercih edilmemelidir. Çünkü bu yönde bir değişiklik olması, tıpkı danışanın her seferinde başka bir uzmanla görüşüp ona karşı yeniden güven kurmaya çalışması durumunda olduğu gibi, terapi sürecini aksatacaktır.

Güven konusunun bu denli önemli olmasının nedenlerinin başında elbette hassasiyetler gelmektedir. Ruh sağllğı desteğinde gerçekleştirilen görüşmelerdeki içerik belirli hassasiyetleri de içinde barındırmaktadır. Bu bakımdan mahremiyetin söz konusu olması, utanma, korku ya da güvensizlik gibi hislerin yaşanmasına neden olabilecektir. Bunun çeşitli etkilerinden biri, danışanın uzman ya da çevirmenle ilgili cinsiyet tercihinin olabilmesidir. Sağlık alanındaki çevirmenlikte bu duruma sıkça rastlanmaktadır (Slapp, 2004, s. 23). Ruh sağlığı alanı söz konusu olduğunda bu hassasiyet daha fazla olacaktır. Bununla birlikte kültürlerarası farklılıkların da yaşanmasıyla hassasiyetler farklılık göstermesi büyük bir olasılıktır. Soruların belirlenmesi, cevapların yorumlanması ve hatta terapi sırasındaki tutum ve davranışlarda bile bu farklılıkların göz önünde bulundurulması gereklidir. Hele ki ağır travmalar ve bunların psikolojik sonuçları üzerine konuşulacağından, danışanın gizlilik konusunda endişe etmemesine dair bilgilendirilmelerin yapılması gerekmektedir.

Bütünsel bir yaklaşımla ifade edecek olursak, çevirmenin süreci uzmanla işbirliği içerisinde, sözü edilen tüm bu dinamikleri göz önünde bulundurarak gerçekleştirmesi, iş ve meslek etiği olarak ifade edilebilir. Tüm çeviri alanlarında geçerliliği olan bu hususların, konu psikoterapi olduğunda süreci etkileyecek kadar etkili olması, tarafların deneyimle ya da rastlantısal olarak bilinçlenmesinden çok uzak, amaçlı ve planlı olarak bilgilendirilmesini gerekli kılmaktadır. Bu bağlamda, söz konusu işbirliğinin altı özellikle çizilmelidir. İşbirliği, kendisini sahada en somut şekilde terapi öncesi ve sonrası çevirmen ve uzman arasındaki görüşmelerde göstermektedir. Bu görüşmelerin ülkemizin mevcut saha uygulamalarındaki işlerliği ayrı bir tartışma konusudur. Ancak çokkültürlü topluma sahip olmaları bakımından toplum hizmetlerinde gelişmiş olan ülkelerde, terapi öncesi ve sonrası görüşmelerin çevirmenle birlikte yürütülen ruh sağlı̆̆ı çalışmalarının vazgeçilmez bir parçası olduğu bilinmektedir7.

Bu konuda örnekler için bkz. NFN - Netzwerk für traumatisierte Flüchtlinge in Niedersachen e.V. Erişim Adresi: https://ntfn3.ntfn.de/therapie-mit-dolmetschenden/standards-und-checkliste1/

Adres 1 Address

RumeliDE Dil ve Edebiyat Araşttrmaları Dergisi $\quad$ RumeliDE Journal of Language and Literature Studies Osmanağa Mahallesi, Mürver Çiçeği Sokak, No:14/8 Osmanağa Mahallesi, Mürver Çiçeği Sokak, No:14/8

Kadıköy - İSTANBUL / TÜRKIYE 34714 Kadıköy - ISTANBUL / TURKEY 34714 e-posta: editor@rumelide.com

e-mail: editor@rumelide.com

tel: +90 505 7958124, +90 2167730616 phone: +90 505 7958124, +902167730616 


\section{b. Terapi öncesi}

Terapi öncesi görüşmenin önemi, terapide etkili olabilecek hususların hem terapi hem çeviri etkinliği açısından konuşularak kararlaştırılmalıdır. Burada söz konusu olabilecek bilgi paylaşımları duruma göre farklılık gösterebilir. Eğer danışan, terapi seansına ilk kez geliyorsa, çevirmen, ihtimaller ve gerekenler konusunda bilgilendirilmelidir. Çünkü ilk görüşme aynı zamanda, terapist açısından da sorunun tespit edilip tedavi yönteminin belirlenmesi açısından büyük önem taşımaktadır. Buna göre, travmaların etkisi olan depresyon, bunalım, anksiyete, psikoz gibi rahatsızlıkların teşhis edilebilmesi için belirtilerinin çok iyi şekilde gözlemlenmesi gerekmektedir. $\mathrm{Bu}$ belirtiler, beden diline yansıyabileceği gibi uzmanın, danışanın dilini bilmemesi nedeniyle fark edemeyeceği konuşma hızı, tonlama, tekrarlama, akıcılık, yanlış kelime kullanımı ve/veya hatalı cümle yapısıyla kendisini ifade ediyor olması gibi etkiler de söz konusu olabilir. ${ }^{8}$ Tam bu noktada çevirmenin bu hususların belirleyiciliğinin farkında olması önemlidir. Terapist, çevirmeni ihtimaller konusunda bilgilendirmeli ve gözlemlerini terapi sonrasında kendisiyle paylaşması gerektiğini çevirmene açıklamalıdır.

Aleksandra Nuč, uzman ve çevirmen arasında terapi öncesi yapılması gerekli olan görüşmenin özellikle danışanla ilgili ön bilgi anlamında konu, bağlam, başvurma nedeni, yaşam şartları; süreç açısından ise terapi metodu, izlenmesi planlanan yöntem, çevirmenin rolü ve süre konularını içermesi gerektiğini vurgulamaktadır. Bununla birlikte çevirmen için önemli olan, terapistin konuşma hızı ve süresi konusunda bilgi vermesidir, bu aynı zamanda aktarım sürecinin sorunsuz geçmesi için de önemlidir (2006, s. 268).

\section{c. Terapi sonrası}

Terapi sonrasında çevirmen ve uzman arasında gerçekleşecek görüşmenin de özellikle terapinin gidişatı ve planlanması bakımından önemli olduğu söylenebilir. Terapi öncesi görüşme çevirmenin hazırlığı bakımından ne kadar önemli ise, terapi sonrasındaki görüşme de uzman açısından o kadar belirleyicidir. İletişimin sorunsuzca gerçekleşip gerçekleşmediği, çeviri süreci açısından aksaklığa neden olan hususlar, uzman açısından aksaklığa neden olan hususlar, çevirmenin dikkatini çeken bir şey olup olmadığı (örnek olarak danışanın konuşma biçimi, kekelemesi, tekrarlaması, takılarak konuşması, bağlantısız ifadeler kullanması, beden dilinde dikkat çeken bir davranış vb.), sosyal ve kültürel ${ }^{9}$ açıdan ifade edilmesi gereken bir durumun olup olmadığı gibi konuların uzman ve çevirmen arasında, terapi sonrasında değerlendirilmesi, danışanın sonraki görüşmelerinin sağlıklı ilerleyebilmesi ve terapinin gerektiği şekilde planlanabilmesi için oldukça önemlidir.

Bu noktada çevirmenin bulunduğu ortam ve şahitlik ettiği ağır yaşanmışlıkların çevirmen üzerinde olumsuz etkisinin olabileceğini de ifade etmek gerekir. Özellikle konu mültecilerin ruh sağlığı olunca görüşmelerin içeriği çevirmenin psikolojisini olumsuz etkileyebilir. Terapi sonrası uzmanla çevirmen arasındaki görüşmeler, çevirmenin bunu ifade etmesi için ve tavsiyeler alması için uygun ortamı sağlayabilir. Bununla birlikte çevirmenler için de bu konuda ayrı bir seans ihtiyacı ortaya çıkabilir. Nitekim çevirmenlerin de danışanla benzer bir hikâyesi olabileceği yukarıda vurgulanmıştı.

ZEBRA - Interkulturelles Beratungs- und Therapiezentrum. Erișim Adresi: https://www.dgspev.de/fileadmin/user_files/dgsp/pdfs/Tagungsberichte_und_Powerpoint/Dolmetschregeln_im_psychotherapeutische n_Setting_1_.pdf

Migranten in Aktion E.V. Gemeindedolmetscher-Dienst Hamburg. Erișim Adresi: http://www.migranten-inaktion.de/fileadmin/Downloads/2016/MiA_Auftragsformular_Dolmetscher.pdf

8 Bu konuya bu çalışmanın Ruh Sağlığı Alanı ve Psikoterapide Görüşsme Teknikleri ve Yöntemleri başlıklı bölümünde değinilmiştir.

Kültür sözsüz davranış ve tutumlara etkili olabilir. Buna göre de bağlam ve duruma göre dikkate alınmalıdır. Bkz. Bahardır, 2010, s.195

RumeliDE Dil ve Edebiyat Araşturmalar Dergisi Osmanağa Mahallesi, Mürver Çiçeği Sokak, No:14/8 Kadıköy - İSTANBUL / TÜRKIYE 34714 e-posta: editor@rumelide.com tel: +90 $5057958124,+902167730616$
Address

RumeliDE Journal of Language and Literature Studies

Osmanağa Mahallesi, Mürver Çiçeği Sokak, No:14/8

Kadıköy - ISTANBUL / TURKEY 34714

e-mail: editor@rumelide.com,

phone: +90 505 7958124, +90 2167730616 


\section{Sonuç ve değerlendirme}

Ruh sağlı̆̆ı alanında yapılan çevirmenlik uygulamaları kapsamında psikoterapi çevirmenliği konusunu odağa alan bu araştırmada, ruh sağlığı alanının dinamikleri ele alınarak, çeviri açısından ortaya çıkan hususlar irdelenmiştir. Bu kapsamda kuramsal ve kavramsal çerçeve oluşturularak, durumsallık ilişkisi bağlamında psikoterapi ve çeviriye etki edecek dinamikler belirlenmiş ve sorunsallaştırılmıştır. Buna göre, çevirmenlerin psikoterapilerdeki rolü ve durumu psikoterapi ve çevirmen ilişkisi açılarından ortaya konmuştur. Yapılan araştırmadan hareketle ve kapsayıcı bir yaklaşımla psikoterapi çevirmenliği, psikolojik destek amaçl görüşmeler sirasında, uzman ve danışan arasında amaçlanan işlev doğrultusunda iletişimin sağlanmasım, öncesi ve sonrası da dahil olmak üzere tüm sürece etki eden aktörleri, faktörleri ve dinamikleri de dikkate alarak olanakh kalan diller-ve kültürlerarası eylem ${ }^{10}$ şeklinde tanımlanabilir.

Bu araştırma kapsamında özel bir alan olarak ruh sağlı̆̆ı hizmetlerinde gerçekleştirilen terapilerin belirleyici özellikleri alan literatürü irdelenerek ortaya konulmuştur. Bu bağlamda, danışan (mülteciler) profili ve ihtiyaçları, görüşme yöntem ve teknikleri, soru türleri gibi bu alandaki temel unsurlarla çevirmenin bu unsurlar odağında terapide üstlendiği sorumluluk ve rolün belirginleşmesi sağlanmıştır. Bununla birlikte, çeviri süreci ve çevirmen rolünü ortaya koymak açısından önemli olan terapi öncesi ve sonrası görüşme, rol, sorumluluk, inisiyatif, empati, tarafsızlık, hassasiyet, saygl, güven, gizlilik gibi kavramlar üzerinden de terapi sırasında sürece etki eden ve dikkate alınması gereken bazı unsurlar açılanmıştır. Bu sayede işbirliğinin gerekliliği somutlaştırılarak çevirmenin rolü ve önemi saptanmıştır.

Psikoterapiler çok farklı dinamiklere sahip ve titizlikle yürütülmesi gereken bir hizmet alanı olması bakımından, çeviriye ihtiyaç duyulan birçok farklı toplum çevirmenliği alanından ayrılmaktadır. Ruh sağlığı, sağlık alanının içinde konumlandırılabilse de hareket noktası ve temeldeki farklılıkları nedeniyle durumsallığı göz önünde bulundurulması gereken bir alt alandır. Bu sürecin sağlıklı yürütülmesine önemli ölçüde etki eden olgulardan birinin çeviri, aktörlerden birinin de çevirmen olduğu ve dinamikleri çok olan bu alanda gerçekleştirilen terapilerde çeviri eyleminin ve çevirmenin belirleyici bir rol oynadığı görülmüştür. Ülkemize beklenmedik bir zamanda, beklenmedik bir yoğunlukta gelen mülteciler için acil iletişim olanaklarının oluşturulması sırasında, durumun da elzem olması bakımından, çevirmen görevlendirmelerinde "iki dili bilmek” kriterinin yeterli görülmüş olması doğal karşılanabilir. Ancak günümüzde, özellikle de çeşitli travmalar yaşamış mültecilere yönelik ruh sağlı̆̆ı hizmetlerinde duruma daha bilinçli yaklaşmak gerekmektedir.

$\mathrm{Bu}$ alandaki terapi sürecinin sağlıkl yürütülmesi ve tüm aktörlerde (uzman, danışan, çevirmen) farkındalık oluşması için bilgilenme ve bilinçlenmenin gerçekleşmesi ve tüm bunların sahaya taşınması son derece önemlidir. Farkındalık, bilgilenme ve sahaya taşıma (FBS) üçlüsü bu alanda, özellikle mültecilere veya bir nedenle Türkiye'de bulunan ve ülke dilini bilmeyen kişilere çevirmen eşliğinde hizmet veren kurum ve kuruluşlarda benimsenmesi ve karşılanması gereken bir ilke olarak görülebilir. $\mathrm{Bu}$ bağlamda tarafların, sürecin roller ve sorumluluklar karışmadan işbirliği ile yürütüleceği konusunda farkındalık kazanması, yukarıda altı çizilen hususları kapsayacak alan bilgisini gerektirmekte ve en önemlisi birlikte işbirliği içinde nasıl çalışılacağı konularında bilgilenmeleri ve tüm bunları sahaya taşıyabilecek pratiği kazanmaları için gerekli ortamın sağlanması gerekmektedir."1

Tanım ve vurgu yazara aittir.

Burada ifade edilen özel alan odaklı bir derinlikte olmasa da bu yönde bir çaba Çeviri Derneği ve Türk Kızılay’ın birlikte gerçekleştirdikleri toplum çevirmenlerine verilen çevirmenlik eğitimlerinde görülmektedir. Bu kapsamda toplum merkezlerinde görev alan kişilere toplum çevirmenliği konusunda iki gün süren eğitimler verilmiş ve senaryo Adres | Address

RumeliDE Dil ve Edebiyat Araşttrmaları Dergisi $\quad$ RumeliDE Journal of Language and Literature Studies Osmanağa Mahallesi, Mürver Çiçeği Sokak, No:14/8 Osmanağa Mahallesi, Mürver Çiçeği Sokak, No:14/8 Kadıköy - İSTANBUL / TÜRKIYE 34714 Kadıköy - ISTANBUL / TURKEY 34714 e-posta: editor@rumelide.com e-mail: editor@rumelide.com, tel: +90 505 7958124, +90 2167730616 phone: +90 505 7958124, +902167730616 
Çevirmenin psikoterapideki rolünü ve önemini araştırarak ortaya koyan bu çalışmanın, ruh sağlığı alanındaki çeviri etkinliği konusunda farkındalık oluştururken, çeşitli teorik araştırmalara ve saha incelemelerine olan ihtiyacın belirginleşmesine de katkı sağlaması beklenmektedir. İki etkinliği konu alan bilim dallarının ortak bir zeminden ve ortak bir amaçla yürüteceği araştırmalar, psikoterapide uzman, çevirmen ve danışan üçgeninde gerçekleşen sürecin sağlıklı şekilde yürütülmesine ve bu alanda çalışan belirli formasyona sahip çevirmenlerin istihdam edilmesi konusunda bakış açısının oluşmasına zemin hazırlayacaktır.

Öte yandan ruh sağlı̆̆ alanının kendine özgü dinamiklerinin, bu çalışma kapsamında işaret edildiği gibi, ciddi şekilde belirleyici olmasının sözlü çeviri konusundaki yöntem ve stratejileri bu alan odağında ve özelinde yeniden tartışmayı ve yorumlamayı gerektirdiğini söylemek yanlış olmayacaktır.

\section{Kaynakça}

Bahadır, Ş. (2007). Verknüpfungen und Verschiebungen. Dolmetscherin, Dolmetschforscherin, Dolmetschausbilderin. Berlin: Frank \& Timme.

Bahadır, Ş. (2010). Dolmetschinszenierungen. Kulturen, Identitäten, Akteure. Berlin: SAXA Verlag.

Bahadır, Ş. (2014). Dolmetschen als Inszenierung - ein neuer kritischer und emanzipatorischer Ansatz in der Dolmetschdidaktik. (Präsentation) DIES LEGENDI: Studierende im Fokus aktivierende Lehre an der JGU. Erişim Adresi: https://www.glk.unimainz.de/files/2018/o8/praesentation_bahadir.pdf

Bahadır, Ş. (2015). Eine körper- und handlungszentrierte Ausbildung von Dolmetschern und Dolmetscherinnen im Grenzbereich anderer Berufe. In: Employability Beschäftigungsbefähigung im Studium an der JGU. s. 47-57.

Cagala, E. (2006). „Eine Frage der Menschlichkeit? Psychotherapie traumatisierter Flüchtlinge mit Dolmetscherinnenbeteiligung“, Grbič, N. \& Pöllabauer, S. (Eds.) „Ich habe mich ganz peinlich gefuihlt." Forschung zum Kommunaldolmetschen in Osterreich: Problemstellungen, Perspektiven und Potenziale içinde (s. 229-260). Graz: GTS - Graz Translation Studies 10.

Demirbaş, H. ve Bekaroğlu, E. (2013). Evden uzakta olmak: Sı̆̆ınmacıların/mültecilerin psikolojik sorunları ve alınacak önlemler. Kriz Dergisi içinde, 21 (1), s.11-24.

Güneri-Yöyen, E. (2020). Klinik Psikolojide Temel Kavramlar. Bal F. (Ed.), Klinik Psikolojide Kullanılan Psikoterapi Yöntemleri içinde (s. 5-12). Ankara: Nobel.

Haenel, F. (2016). Zum Einsatz von Dolmetschern in der psychiatrisch-psychotherapeutischen Versorgung von Geflüchteten. In ASU - Zeitschrift für medizinische Prävention, 51 (12). s. 836838.

Holmes, J. S.(2008). Çeviribilimin Adı ve Doğası. (Ayşenaz Koş Çev.). Mehmet Rıfat (Ed.) Çeviri Seçkisi II: Çeviri(bilim) Nedir? içinde (s. 107-120). İstanbul: Sel.

Holz-Mänttäri, J. (1984). Translatorisches Handeln: Theorie und Methode. Helsinki: Suomalainen Tiedeakatemia.

Kahraman, R. (2010). Göç ve Çeviri: İltica Başvurularmda Sözlü Çeviri Uygulamalar ve Toplum Çevirmeninin Rolü (Doktora Tezi), İstanbul Üniversitesi Sosyal Bilimler Enstitüsü, İstanbul.

Kurultay, T. ve Bulut, A. (2012). Toplum Çevirmenliğine Yeniden Bakışta Afette Rehber Çevirmenlik, İ.Ü. Çeviribilim Dergisi, 6 (2-2012), 75-102.

uygulamaları yapılmıştır. Psikoterapi çevirmenliği özelinde yine Türk Kızılay toplum merkezlerinde bu alanda uzmanlarla birlikte çalışan çevirmenlere "Kızılay Toplum Merkezleri Ruh Sağllğı Hizmetleri Çevirmen Eğitimi" programı kapsamında üç haftalık bir eğitim verilmiștir. Bu gibi dil bilen kişi ya da kurum çalışanlarına yönelik eğitim örnekleri hem yurtiçinde hem de yurt dişında (bkz. Salman, 2007, s. 248; Meyer, 2003, s. 162; Bahadır, 2014) görülmektedir.

RumeliDE Dil ve Edebiyat Araştırmaları Dergisi Osmanağa Mahallesi, Mürver Ciceği Sokak, No:14/8 Kadıköy - İSTANBUL / TÜRKIYE 34714 e-posta: editor@rumelide.com tel: +90 $5057958124,+90216773$ o 616
Address

RumeliDE Journal of Language and Literature Studies Osmanağa Mahallesi, Mürver Çiçeği Sokak, No:14/8

Kadıköy - ISTANBUL / TURKEY 34714

e-mail: editor@rumelide.com,

phone: +90 $5057958124,+90216773$ o 616 
Mesleki Yeterlilik Kurumu, Toplum Çevirmenliği Ulusal Yeterlilik Kriterleri. Erişim Adresi: http://cdn.istanbul.edu.tr/FileHandler2.ashx?f=cevirmen-yeterlilikleri---toplum-cevirmeni--yayinlanan-taslak-15.12.2018.pdf

Meyer, B. (2003). Dolmetschertraining aus diskursanalytischer Sicht: Überlegungen zu einer Fortbildung zweisprachiger Pflegekräfte. In Gesprächsforschung - Online-Zeitschrift zur verbalen Interaktion 4. Ausgabe, 160-185.

Migranten in Aktion E.V. Gemeindedolmetscher - Dienst Hamburg. Erişim Adresi: http://www.migranten-inaktion.de/fileadmin/Downloads/2016/MiA_Auftragsformular_Dolmetscher.pdf

NFN - Netzwerk für traumatisierte Flüchtlinge in Niedersachen e.V.. Erişim Adresi: https://ntfn3.ntfn.de/therapie-mit-dolmetschenden/standards-und-checkliste1/

Nuč, A. (2006). Wenn Welten aufeinander treffen... Dolmetschen in der Psychotherapie. In Grbič, N. \& Pöllabauer, S. (Eds.) „Ich habe mich ganz peinlich gefühlt." Forschung zum

Kommunaldolmetschen in Osterreich: Problemstellungen, Perspektiven und Potenziale (s. 261296). Graz: GTS - Graz Translation Studies 10.

Pöchhacker, F. (2010). Entwicklungslinien der Dolmetschwissenschaft. In N. Grbić, G. Hebenstreit, G. Vorderobermeier \& M. Wolf (Eds.), Translationskultur revisited: Festschrift für Erich Prunč (s. 84-97). Tübingen: Stauffenburg Verlag.

Ross, J. (2018). Toplum Çevirmenliği Eğitimi. E. Diriker (Ed.), Türkiye’de Sözlü Çeviri Eğitimi, Uygulamaları ve Araşttrmaları içinde (s. 283-312). İstanbul: Scala.

Salman, R. (2007). Gemeindedolmetscherdienste als Beitrag zur Integration von Migranten in das regionale Sozial- und Gesundheitswesen - das Modell des Ethno-Medizinischen Zentrums. In Gesundheit und Integration - Ein Handbuch für Modelle guter Praxis (Hrsg.), Die Beauftragte der Bundesregierung für Migration, Flüchtlinge, und Integration (s. 246-256). Bonn.

Slapp, M. A. (2004). Community Interpreting in Deutschland: Gegenwärtige Situation und Perspektiven für die Zukunft. (1.bs.). München: Martin Meidenbauer Verlagsbuchhandlung.

Şan, F. ve Koçlu, S. (2018). Sakarya'daki Mültecilerin İletişim Sorunlarının Belirlenmesi ve Toplum Çevirmenliğine Olan İhtiyaç. International Journal of Language Academy, 4(6), 1-16.

Şan, F. ve Kahraman - Duru, R. (2020). COVID 19 koşullarında sağlık çevirmenliği hizmetleri ve toplum çevirmenliğinde "Yeni Normal"'i düşünmek. RumeliDE Dil ve Edebiyat Araştırmalar Dergisi, (20), 816-843.

Şan, F. ve Koçlu, S. (2020). Toplum Çevirmenliği Alanında Türkiye'de Yapılan Bilimsel Çalışmalar: Analiz ve Değerlendirme. RumeliDE Dil ve Edebiyat Araştırmaları Dergisi, (19), 785-808.

TDK Sözlük. "Uyum”. Erişim Bilgisi: https://sozluk.gov.tr/

Turan, D. (2016). Sağlık Hizmetlerinde Sözlü Çeviri Hizmetleri (1.bs.). Ankara: Grafiker.

Yüksel-Şahin, F. (2019). Psikolojik Danışmanlar için El Kitabı (3.bs.). Ankara: Nobel.

ZEBRA - Interkulturelles Beratungs- und Therapiezentrum, Erişim Adresi: https://www.dgspev.de/fileadmin/user_files/dgsp/pdfs/Tagungsberichte_und_Powerpoint/Dolmetschregeln_i m_psychotherapeutischen_Setting_1_.pdf

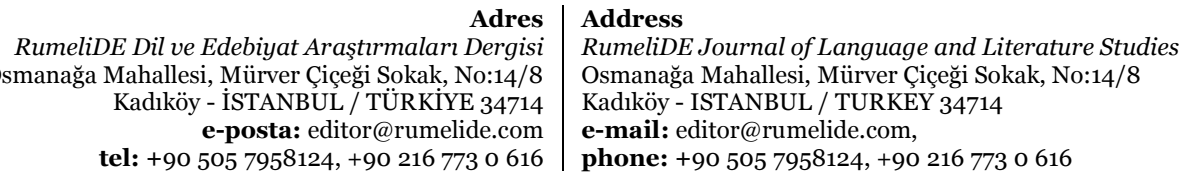

RumeliDE Dil ve Edebiyat Araştırmaları Dergisi e-posta: editor@rumelide.com tel: +90 $5057958124,+902167730616$
Address

Osmană̆a Mall

e-mail: editor@rumelide.com

phone: +90 $5057958124,+902167730616$ 